\title{
Sexual dimorphism of human vallate papillae: an in vivo study of normative morphology
}

\author{
M.J. Zdilla1 ${ }^{1}$, L.N. Gibson ${ }^{1}$, A.J. Hunt ${ }^{2}$ \\ ${ }^{1}$ Department of Natural Sciences and Mathematics, West Liberty University, West Liberty, West Virginia, United States \\ ${ }^{2}$ Sarah Whitaker Glass School of Dental Hygiene, West Liberty University, West Liberty, West Virginia, United States
}

[Received 9 August 2014; Accepted 29 August 2014]

\begin{abstract}
The perimeters of vallate papillae (VP) house approximately half of the taste buds on the human tongue. However, little information exists regarding perimeter measurements of VP. Likewise, great diversity exists among reports of the number of VP and diameter of VP, in general. The research presents an analysis of the perimeters, counts, and diameters of VP in vivo. Endoscopic examination was performed on 79 individuals (40 females, 39 males) between 18 and 26 years of age. A total of 583 VP were counted, 565 of which were able to be measured. Data revealed a statistically significant difference between male and female VP count $(t(75.6)=4.5$; $p=0.00003)$. Females had, on average, 2.22 more VP than males. Males were found to have larger mean VP diameter per person and mean VP perimeter per person than females $(t$ (58.9) $=-2.4 ; p=0.021$ and $t$ (59.3) $=-2.4 ; p=0.019$, respectively). The report demonstrates that VP are sexually dimorphic at the gross anatomical level. (Folia Morphol 2015; 74, 2: 245-251)
\end{abstract}

Key words: circumvallate papillae, gustation, gustatory papillae, lingual papillae, taste, taste buds, tongue

\section{INTRODUCTION}

\section{Vallate papillae}

The detailed structure of the tongue was first described by Casserius in 1609 and later, the lingual papillae of the tongue were further expounded by Marcello Malpighius and Lorenzo Bellini in 1664 and 1665, respectively [46]. Vallate papillae (VP), commonly referred to as circumvallate papillae, are lingual papillae, located at the posterior dorsum of the tongue, which form a V-shaped row immediately anterior to the sulcus terminalis [35]. The VP, unlike other lingual papillae, receive innervation from the glossopharyngeal nerves [35]. Developmentally, VP are among the first lingual papillae to form in utero, having been reported to develop as early as the $4^{\text {th }}$ week of embryonic development [20]. Currently, the earliest photographic evidence demonstrates that VP anlagens are well defined by the $6^{\text {th }}$ embryonic week [45].

Among all of the gustatory papillae, VP are the largest and can be seen macroscopically with little effort. Therefore, it is unusual that little agreement has existed regarding the count of VP in humans (Table 1). Most descriptions of VP are found among textbooks and are likely arbitrary estimates of VP counts which document ranges of VP without also identifying important information including demographics such as sex, race, and age. Such demographical information has been documented to have influence over VP morphology. Age, for example, may contribute to the diversity among VP count ranges because, in the elderly, lateral VP undergo involution [2].

Address for correspondence: M.J. Zdilla, D.C., Associate Professor of Biology, West Liberty University, Department of Natural Sciences and Mathematics, CSC 139; P.O. Box 295, West Liberty, WV 26074, United States, tel: +1 304-336-8631, fax: +1 304-336-8266, e-mail: mzdilla@westliberty.edu 
Table 1. Reports of the estimated number of vallate papillae (VP) present in the human tongue

\begin{tabular}{|c|c|c|}
\hline \multirow[t]{2}{*}{ Author(s) } & \multicolumn{2}{|c|}{ Range of VP\# } \\
\hline & Low & High \\
\hline Cruveilheir* & 16 & 20 \\
\hline Marjolin* & 9 & 15 \\
\hline Sömmering* & 12 & 14 \\
\hline Meckel $^{*}$ & 3 & 20 \\
\hline Freudenreich (1833) [17] & 7 & 9 \\
\hline Ridge (1844) [33] & 9 & 15 \\
\hline Harrison (1848) [18] & 12 & 16 \\
\hline Hassall (1849) [19] & 7 & 8 \\
\hline Todd and Bowman (1850) [39] & 8 & 10 \\
\hline Richardson (1854) [32] & 15 & 20 \\
\hline Folsom (1863) [16] & 7 & 15 \\
\hline Kirkes (1867) [23] & 8 & 10 \\
\hline Flint (1889) [15] & 7 & 12 \\
\hline M'Kendrick and Snodgrass (1893) [27] & 8 & 15 \\
\hline Loveland (1897) [24] & 7 & 10 \\
\hline Stöhr (1901) [36] & 8 & 15 \\
\hline Ferguson (1909) [13] & 8 & 12 \\
\hline Broomell and Fischelis (1913) [4] & 6 & 12 \\
\hline Hollingsworth and Poffenberger (1917) [20] & 8 & 16 \\
\hline Walmsley (1922) [40] & 8 & 12 \\
\hline Cruzon-Miller (1922) [9] & 10 & 13 \\
\hline Bödecker (1926) [3] & 9 & 10 \\
\hline Kamath (1982) [22] & 7 & 12 \\
\hline Miller and Bartoshuk (1991) [26] & 3 & 13 \\
\hline Nelson (1998) [28] & 12 & 15 \\
\hline Jung et al. (2004) [21] & 7 & 9 \\
\hline Standring (2008) [35] & 8 & 12 \\
\hline
\end{tabular}

\#Ranges were likely reported as estimates

${ }^{*}$ As documented by Todd (1852) Cyclopedia of Anatomy and Physiology [38]

As the name suggests, each VP is surrounded by a vallum, a small mound of tissues, which creates a sulcus around the papilla. The inner surface of the vallum (the perimeter of the VP) houses an average of 250 taste buds [35]. About $50 \%$ of the taste buds located on the tongue are located at the VP [30]. Despite the well-established existence of the many taste buds located along the perimeters of VP, little data exists regarding VP perimeter measurements. Likewise, other morphological data, including VP diameter, has been described, but most of these data are widely diverse and likely estimated, too (Table 2).
Table 2. Data documenting the diameter of vallate papillae present in the human tongue

\begin{tabular}{lcc}
\hline Author(s) & \multicolumn{2}{c}{ Range of diameter [mm $]^{\S}$} \\
\cline { 2 - 3 } & Low & High \\
\hline Todd and Bowman (1850) [39] & $1 / 20^{\text {th }} \mathrm{in}^{*}$ & $1 / 12^{\text {th }} \mathrm{in}^{*}$ \\
Todd ed. (1852) [38] & - & $1 / 8^{\text {th }} \mathrm{in}^{\dagger}$ \\
Kirkes (1867) [23] & $1 / 20^{\text {th }} \mathrm{in}^{*}$ & $1 / 12^{\text {th }} \mathrm{in}^{*}$ \\
Cunningham (1903) [10] & 1 & 2.5 \\
Hollingsworth and Poffenberger & 1.0 & 1.5 \\
(1917) [20] & & \\
Broomell and Fischelis (1913) [4] & - & $1 / 4^{\text {th }} \mathrm{in}^{\ddagger}$ \\
Standring ed. (2008) [35] & 1 & 2 \\
\hline
\end{tabular}

§Ranges were likely reported as estimates; ${ }^{*} 1 / 20^{\text {th }}$ in $=1.27 \mathrm{~mm} ; 1 / 12^{\text {th }}$ in $=2.17 \mathrm{~mm}$; ${ }^{\dagger} 1 / 8^{\text {th }}$ in $=3.18 \mathrm{~mm} ;{ }^{\ddagger} 1 / 4^{\text {th }}$ in $=6.35 \mathrm{~mm}$

\section{Gustation}

Despite the paucity of well-documented gross anatomical information regarding VP, there is a large body of knowledge regarding taste function and the importance of taste, in general. Taste, especially bitter taste perception, allows for the evaluation of foods that may contain poisons such as plant alkaloids and fermentation products resulting from bacterial contamination [11, 31]. Likewise, taste is linked to human health by way of biased food selection [1, 29, 37, 47]. Biased food selection and differences in eating behaviour, in general, have been linked to differences in sex $[6,7,12,34,41,42,44,48]$. Similarly, numerous studies have noted differences in taste perception between males and females, especially with regard to bitter taste $[5,8,14,43]$.

\section{Purpose and rational}

The following report formally documents VP count and gross morphology and accounts for salient details including demographics, methods of data acquisition, and statistical analysis. The relationship between VP count and diameter is explored, as well. Because prior reports have documented differences in gustatory physiology between sexes, the authors rationalised that, likewise, males and females may have apparent sexual differences in gustatory anatomy. Therefore, the report also compares VP morphology between sexes.

\section{MATERIALS AND METHODS}

\section{Sample}

Research was approved by the West Liberty University Human Subjects Committee. Individuals 
participated in the study voluntarily. A total of 79 Caucasian individuals (40 females and 39 males) with an average age of $20.6 \pm 1.6$ years (mean \pm standard deviation) volunteered for participation in the study. The female and male age ranges were the same (18-26 years). Similarly, the average age of each sex was approximately the same, the female average age was $20.3 \pm 1.6$ years and the male average age was $20.9 \pm 1.5$ years. Data, including VP count, was collected from all 79 individuals; however, researchers were not capable of collecting adequate morphological measurements from all participants ( 1 female and 1 male, respectively). A total of 583 VP were counted and 565 VP were measured.

\section{Methods}

In vivo endoscopy was performed with an intraoral camera (Dentamerica Cammy, 1.3 Megapixels) and photographs were taken to assess the morphological characteristics of the VP. Each participant opened their mouth and protruded their tongue to allow access to the posterior dorsum of the tongue. The intraoral camera, sleeved for infection control, was inserted into the oral cavity with care not to touch surrounding anatomy, in order to avoid subject discomfort. Vallate papillae were identified on a computer screen and counted (Fig. 1).

A flattened probe, curved to negotiate the contour of the tongue (convex dorsally, concave ventrally), with a circular reference dot of known diameter $(6.25 \mathrm{~mm}$; $0.25 \mathrm{in}$ ) located at its tip was utilised as a reference. Intraoral camera sleeves were used to cover the probe for infection control. The probe was manipulated to position the reference dot next to the VP so that both the reference dot and VP could be photographed together. VP morphology was then measured with ImageJ software, utilising the known diameter of the circular dot as a reference for pixel calibration.

Placing the reference dot near the papillae was accomplished with the most ease at the VP located most anterolaterally. In most of the subjects, the probe was not able to be positioned next to the posterior-most papillae due to discomfort (i.e., the gag reflex). In these cases, the diameters of the anterolateral papillae, which had been measured with the reference dot, were then calibrated as references for the posteromedial papillae.

Morphological measurements included papilla perimeter and width. Previous reports have documented estimated VP diameter; however, VP are not

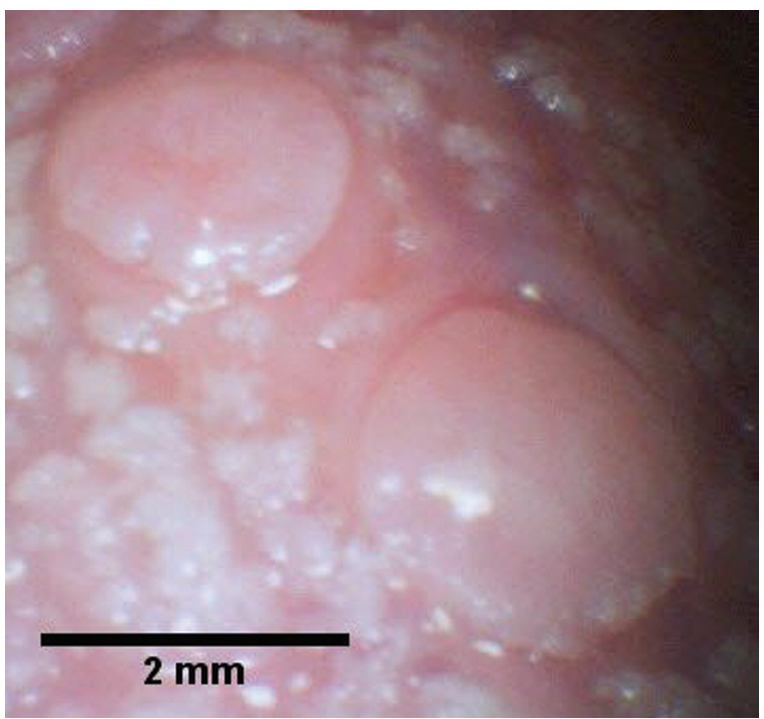

Figure 1. In vivo endoscopic presentation of two vallate papillae (VP). The VP are non-keratinised, and therefore appear pink in colour. Surrounding the VP are numerous filiform papillae which appear white due to their keratinisation. The VP are easily identified and differentiated from surrounding structures based on colour, size, and shape.

perfectly circular. Because VP are not perfectly circular, measurements were taken at the widest and narrowest widths of each papilla and averaged for a 'diameter' measurement.

\section{Statistical analysis}

The statistical software, Statistical Package for the Social Sciences (IBM SSPS Statistics 20) was used for all of the statistical analyses depicted herein except for the D'Agostino-Pearson omnibus K2 test for normality, which was accomplished via GraphPad Prism software (Version 6). Likewise, all graphical representations included in this report were produced via GraphPad Prism.

\section{RESULTS}

\section{Count}

A total of 583 VP were counted and 565 VP were measured (96.9\%). The average number of VP among all individuals $(n=79)$ was $7.38 \pm 2.46$ VP per person. Males had an average of 2.22 VP less than females $(6.26 \pm 2.02$ per male, $n=39 ; 8.48 \pm 2.37$ per female, $n=40$, respectively). The lowest count of VP was in a male who had a complete absence of VP. A female had the highest count of VP with a total of 15. As assessed by the D'Agostino-Pearson omnibus K2 


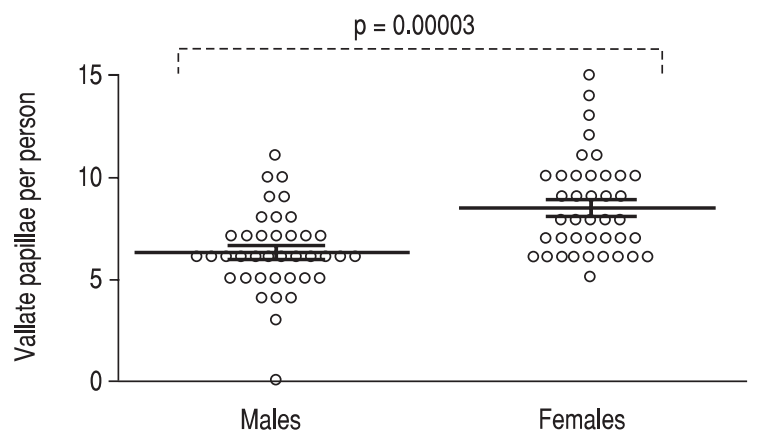

Figure 2. Scatter dot plot demonstrating the statistically significant difference between male and female vallate papillae (VP) counts $(t(75.6)=4.5 ; p=0.00003)$. Males $(n=39)$ had an average of $6.26 \pm 0.32$ (mean \pm SEM) VP per person and females $(n=40)$ had an average of $8.48 \pm 0.38$, respectively. Most males and females were found to have six VP $(\operatorname{mode}=6)$.

test, both male and female VP counts fit a normal distribution $(\mathrm{K} 2=4.17, \mathrm{p}=0.124$ and $\mathrm{K} 2=5.9$, $p=0.052$, respectively). The Student's $t$ test was performed to explore differences between sexes. There was a statistically significant difference between total number of VP per person between sexes $(t(75.6)=4.5$; $p=0.00003$ ) (Fig. 2).

\section{Perimeter}

The average total perimeter of VP per person was $32.22 \pm 12.85 \mathrm{~mm}$. The average total perimeter of male $(n=38)$ VP was $30.63 \pm 14.44 \mathrm{~mm}$ per male, whereas the female $(n=39)$ average was $33.77 \pm$ $\pm 11.07 \mathrm{~mm}$ (Table 3). No significant differences were found between the total VP perimeter per person among sexes $(t(69.4)=1.1 ; p=0.29)$. However, a significant difference was found between male and female mean VP perimeter per person $(t(59.3)=$ $=-2.4 ; p=0.019$ ) (Table 4). On average, females had a mean VP perimeter per person $0.85 \mathrm{~mm}$ less than that of males (Fig. 3).

\section{Diameter}

The average VP diameter per person was $1.41 \pm$ $\pm 0.49 \mathrm{~mm}$. There was a statistically significant difference between male and female average VP diameter per person $(t(58.9)=-2.4 ; p=0.021)$ (Table 4). On average, females had a mean VP diameter per person $0.26 \mathrm{~mm}$ narrower than that of males (Fig. 4). The mean VP diameter per person was found, via Pearson's $r$, to have a weak negative statistically significant correlation with VP count per person among the total population $(r=-0.29$, $p=0.011, n=76$ ). Likewise, females had a moderate negative statistically significant correlation between VP diameter per person and VP count per person $(r=-0.36, p=0.025, n=39)$. However, no correlation existed between male VP diameter per person and VP count per person $(r=-0.10$, $p=0.573, n=37)$.

\section{DISCUSSION}

Little morphological information, aside from estimated ranges of both VP count and diameter, has been documented regarding VP gross anatomy.

Table 3. Descriptive statistics of vallate papillae (VP) per person among the sample population and sexes

\begin{tabular}{|c|c|c|c|c|c|c|c|}
\hline \multirow[t]{2}{*}{ VP parameter } & \multirow[t]{2}{*}{ Population } & \multicolumn{2}{|c|}{ Range } & \multirow[t]{2}{*}{ Median } & \multirow[t]{2}{*}{ Mean } & \multirow[t]{2}{*}{ $\pm S D$} & \multirow[t]{2}{*}{ \pm SEM } \\
\hline & & Min & Max & & & & \\
\hline \multirow[t]{3}{*}{ Count per person } & Total population $(\mathrm{n}=79)$ & 0 & 15 & 7 & 7.38 & 2.46 & 0.28 \\
\hline & Males ( $\mathrm{n}=39$ ) & 0 & 11 & 6 & 6.26 & 2.02 & 0.32 \\
\hline & Females $(n=40)$ & 5 & 15 & 8 & 8.48 & 2.37 & 0.38 \\
\hline \multirow{3}{*}{$\begin{array}{l}\text { Total perimeter [mm] } \\
\text { per person }\end{array}$} & Total population $(\mathrm{n}=77)$ & 0 & 71.4 & 30.07 & 32.22 & 12.85 & 1.46 \\
\hline & Males $(\mathrm{n}=38)$ & 0 & 71.4 & 27.61 & 30.63 & 14.44 & 2.34 \\
\hline & Females $(n=39)$ & 17.1 & 62.6 & 30.68 & 33.77 & 11.07 & 1.77 \\
\hline \multirow{3}{*}{$\begin{array}{l}\text { Mean perimeter }[\mathrm{mm}] \\
\text { per VP per person }\end{array}$} & Total Population $(\mathrm{n}=76)$ & 1.7 & 11.9 & 4.3 & 4.52 & 1.56 & 0.18 \\
\hline & Males $(\mathrm{n}=37)$ & 2.29 & 11.9 & 4.86 & 4.96 & 1.83 & 0.30 \\
\hline & Females $(n=39)$ & 1.71 & 7.32 & 4.09 & 4.11 & 1.13 & 0.18 \\
\hline \multirow{3}{*}{$\begin{array}{l}\text { Mean papilla diameter }[\mathrm{mm}] \\
\text { per person }\end{array}$} & Total population $(\mathrm{n}=76)$ & 0.52 & 3.81 & 1.32 & 1.41 & 0.49 & 0.06 \\
\hline & Males ( $n=37)$ & 0.71 & 3.81 & 1.53 & 1.55 & 0.58 & 0.10 \\
\hline & Females $(n=39)$ & 0.52 & 2.23 & 1.26 & 1.28 & 0.35 & 0.06 \\
\hline
\end{tabular}

Min — minimum; Max — maximum; SD — standard deviation; SEM — standard error of the mean 
Table 4. Comparison of vallate papillae (VP) count, perimeter, and diameter between sexes

\begin{tabular}{|c|c|c|c|c|c|c|c|c|}
\hline \multirow[t]{2}{*}{ VP parameter } & \multicolumn{2}{|c|}{ Mean \pm SEM } & \multirow[t]{2}{*}{$t$} & \multirow[t]{2}{*}{ df } & \multirow[t]{2}{*}{$\mathbf{P}$} & \multirow{2}{*}{$\begin{array}{c}\text { Mean } \\
\text { difference }\end{array}$} & \multicolumn{2}{|c|}{$95 \% \mathrm{Cl}$} \\
\hline & Males & Females & & & & & Lower & Upper \\
\hline Count per person & $\begin{array}{l}6.26 \pm \\
\pm 0.32\end{array}$ & $\begin{array}{l}8.48 \pm \\
\pm 0.38\end{array}$ & 4.7 & 75.6 & $0.00003^{*}$ & 2.22 & 1.23 & 3.21 \\
\hline $\begin{array}{l}\text { Total perimeter }[\mathrm{mm}] \\
\text { per person }\end{array}$ & $\begin{array}{c}30.63 \pm \\
\pm 2.34\end{array}$ & $\begin{array}{r}33.77 \pm \\
\pm 1.77\end{array}$ & 1.1 & 69.4 & 0.29 & 3.13 & -2.72 & 8.99 \\
\hline $\begin{array}{l}\text { Mean perimeter }[\mathrm{mm}] \\
\text { per person }\end{array}$ & $\begin{array}{l}4.96 \pm \\
\pm 0.30\end{array}$ & $\begin{array}{l}4.11 \pm \\
\pm 0.18\end{array}$ & -2.4 & 59.3 & $0.019 *$ & -0.85 & -1.54 & -0.14 \\
\hline $\begin{array}{l}\text { Mean papilla diameter [mm] } \\
\text { per person }\end{array}$ & $\begin{array}{l}1.55 \pm \\
\pm 0.10\end{array}$ & $\begin{array}{l}1.28 \pm \\
\pm 0.06\end{array}$ & -2.4 & 58.9 & $0.021 *$ & -0.26 & -0.49 & -0.04 \\
\hline
\end{tabular}

*Denotes statistical significance $(\mathrm{p}<0.05)$; $\mathrm{Cl}$ — confidence interval; SEM — standard error of the mean

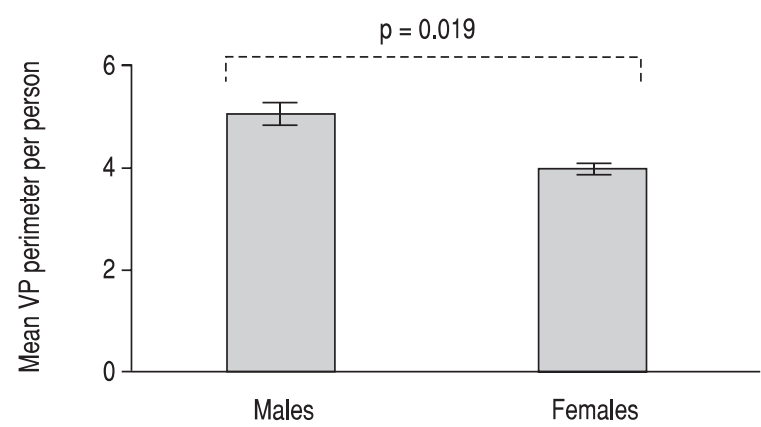

Figure 3. Bar chart demonstrating the statistically significant difference between male and female mean vallate papillae (VP) perimeter per person $(\mathrm{t}(59.3)=-2.4 ; \mathrm{p}=0.019)$. Males $(\mathrm{n}=37)$ had a mean VP perimeter per person of $4.96 \pm 0.30 \mathrm{~mm}$ (mean \pm SEM) and females $(n=39)$ had an average of $4.11 \pm 0.18 \mathrm{~mm}$, respectively.

Salient information including demographics and measurement techniques have been largely absent from prior reports. The research presented herein has included details of VP count, perimeter, and diameter. The report also identifies demographics (including race, sex, and age), sampling methods, measurement techniques, and statistical methodology. To the authors' knowledge, this report is the first to identify statistically significant differences between VP count, mean diameter per person, and mean perimeter per person between males and females.

In 1999, Mavi and Ceyhan compared the VP of young and elderly males and females in a Turkish population [25]. They counted VP by visual inspection with a tongue depressor. With respect to both sex and age, they noted no differences in VP number. Conversely, this report identifies a significant difference between male and female VP count. A comparison of Mavi and Ceyhan's [25] findings with the findings of this report can be found in Table 5 .

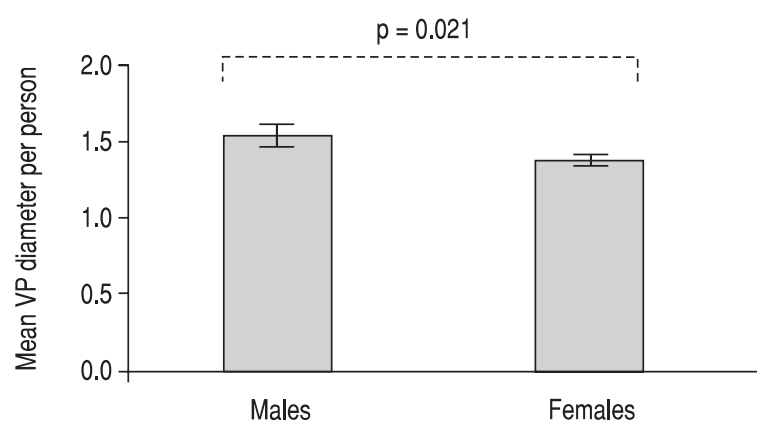

Figure 4. Bar chart demonstrating the statistically significant difference between male and female mean vallate papillae (VP) diameter per person $(t(58.9)=-2.4 ; p=0.021)$. Males $(n=37)$ had a mean VP diameter per person of $1.55 \pm 0.10 \mathrm{~mm}$ (mean \pm SEM) and females $(n=39)$ had an average of $1.28 \pm 0.06 \mathrm{~mm}$, respectively.

Mavi and Ceyhan [25] noted an inverse relationship between VP count and diameter; however, they correlated arbitrary VP count groupings of $<6,6$, or $>6$ VP with arbitrary diameter groupings $\leq 1 \mathrm{~mm}$, $\geq 1-2 \mathrm{~mm}$, and $\geq 2 \mathrm{~mm}$, with no description of statistical methods or results aside from " $(p<0.05)$ ". Conversely, the diameter data from this report (Zdilla et al.) was assessed as parametric data. Among the total sample population of this report, there was a weak statistically significant negative correlation between VP diameter and VP count. When examining the relationship between VP diameter and count in each respective sex, a moderate negative statistically significant correlation was found among females but not among males. At least partially, the results of this study corroborate those of Mavi and Ceyhan [25] with regard to VP count and diameter.

Numerous studies have noted differences in taste acuity between males and females, especially with regard to bitter taste $[5,8,14,43]$. Similarly, sex has 
Table 5. The comparison of the number of vallate papillae (VP) between Turkish young and elderly females and males with the young females and males of this study

\begin{tabular}{|c|c|c|c|c|c|c|}
\hline \multirow[t]{2}{*}{ Author(s) } & \multicolumn{4}{|c|}{ Sample } & \multirow{2}{*}{$\begin{array}{l}\text { Mean VP } \\
\text { count }\end{array}$} & \multirow{2}{*}{$\begin{array}{l}\text { Standard } \\
\text { deviation }\end{array}$} \\
\hline & Sex & Sample size & Age range & Mean age & & \\
\hline \multirow[t]{4}{*}{ Mavi and Ceyhan (1999) [25] } & Female & 15 & $18-25$ & 20.2 & 6.3 & 2.0 \\
\hline & & 10 & $60-80$ & 66.6 & 6.4 & 1.2 \\
\hline & Male & 15 & $17-20$ & 19.3 & 5.4 & 1.1 \\
\hline & & 14 & $60-85$ & 71.2 & 5.9 & 1.8 \\
\hline \multirow[t]{2}{*}{ Zdilla et al. (current study) } & Female & 40 & $18-26$ & 20.3 & 8.5 & 2.4 \\
\hline & Male & 39 & $18-26$ & 20.9 & 6.3 & 2.0 \\
\hline
\end{tabular}

been demonstrated to contribute to biased food preference and differences in eating behaviour $[6,7,12$, $34,41,42,44,48]$. While gustation is multifaceted, the difference between male and female VP count described herein may be of potential influence to sexual differences in taste acuity, hedonics, and biased food preference. One could hypothesize that if females have an average of 2.22 VP more than males, and each VP possesses an average of 250 taste buds, then females would have an average of 555 taste buds more than males along their VP. However, because no studies have yet determined the number of taste buds per VP perimeter length or the number of taste buds per VP tissue area, the sexual dimorphism of average VP perimeter per person is difficult to translate into gustatory function. Future studies should explore taste bud density in VP and the relationship between VP anatomy and taste physiology, in general, with special attention toward sexual dimorphism.

\section{CONCLUSIONS}

Vallate papillae house approximately half of the taste buds on the human tongue. However, little information, aside from estimated ranges of both VP count and diameter, has been documented regarding VP gross anatomy. Likewise, great diversity exists among reports of the number of VP and diameter of VP, in general. Salient information including demographics and measurement techniques have been largely absent from prior reports. This report has documented demographic information as well as measurement techniques. To the authors' best knowledge, this report is the first to identify sexual dimorphism of VP. Females tended to have more VP per person than males; however, males tended to have larger mean VP diameter and perimeter per person than females.

\section{ACKNOWLEDGEMENTS}

The work was supported by grant funding from the Human Anatomy and Physiology Society, the West Virginia IDeA Network for Biomedical Research Excellence [P20GM103434], and NIH-NIAID [5K22AI087703].

\section{REFERENCES}

1. Anliker JA, Bartoshuk L, Ferris AM, Hooks LD (1991) Children's food preferences and genetic sensitivity to the bitter taste of 6-n-propylthiouracil (PROP). Am J Clin Nutr, 54: 316-320.

2. Arey LB, Tremaine MJ, Monzingo FL (1935) The numerical and topographical relations of taste buds to human circumvallate papillae throughout the life span. Anat Rec, 64: 9-25.

3. Bödecker CF (1926) Fundamentals of dental histology and embryology: in drawings and text, with appendix of microscopic technique. The Macmillan Company, New York, p. 165.

4. Broomell IN, Fichelis P (1913) Anatomy and histology of the mouth and teeth. 4th Ed. P. Blakiston's Son \& Co., Philadelphia, p. 27.

5. Cohen T, Gitman L (1959) Oral complaints and taste perception in the aged. J Gerontol, 14: 294-298.

6. Conner M, Johnson C, Grogan S (2004) Gender, sexuality, body image and eating behaviours. J Health Psychol, 9: 505-515.

7. Cooke $\sqcup$, Wardle J (2005) Age and gender differences in children's food preferences. Br J Nutr, 93: 741-746.

8. Cowart BJ (1989) Relationships between taste and smell across the adult life span. Ann NY Acad Sci, 561: 39-55.

9. Cruzon-Miller AG (1922) Physiology for dental students. E. Arnold \& Co., London, p. 31.

10. Cunningham DJ ed. (1903) Text-book of anatomy. William Wood and Company, New York, p. 954.

11. Drewnowski A, Gomez-Carneros C (2000) Bitter taste, phytonutrients, and the consumer: a review. Am J Clin Nutr, 72: 1424-1435.

12. Fagerli RA, Wandel M (1999) Gender differences in opinions and practices with regard to a "healthy diet". Appetite, 32: 171-190. 
13. Ferguson JS (1909) Normal histology and microscopical anatomy. D. Appleton \& Co, New York, pp. 267-269.

14. Fikentscher R, Roseburg B, Spinar H, Bruchmüller W (1977) Loss of taste in the elderly: sex differences. Clin Otolaryngol Allied Sci, 2: 183-189.

15. Flint A (1889) A text-book of human physiology. 4th Ed. D. Appleton \& Co, New York, p. 669.

16. Folsom N (1863) The senses of smell and taste. Boston Med Surg J, 68: 231-238.

17. Freudenrich AHA (1833) De lingua. Diss Inaug Med Chir p. 6.

18. Harrison R (1848) A text-book of practical anatomy. In: Watts R ed. S.S. and W. Wood, New York, p. 494.

19. Hassall AH (1849) The microscopic anatomy of the human body in health and disease, Vol. 1. Samuel Highly, London, p. 497.

20. Hollingsworth HL, Poffenberger AT (1917) The sense of taste. In: Dearborn GVN ed. Moffat, Yard and Co., New York, pp. 70-71, 116-127.

21. Jung HS, Akita K, Kim JY (2004) Spacing patterns on tongue surface-gustatory papilla. Int J Dev Biol, 48: 157-161.

22. Kamath SK (1982) Taste acuity and aging. Am J Clin Nutr, 36: 766-775.

23. Kirkes WS (1867) Hand-book of physiology. 6th Ed. In: Baker WM ed. James Walton, London, pp. 658-659.

24. Loveland AE (1897) A study of the organs of taste. T Am Microsc Soc, 19: 141.

25. Mavi A, Ceyhan O (1999) Bitter taste thresholds, numbers and diameters of circumvallate papillae and their relation with age in a Turkish population. Gerodontology, 16: 119-122.

26. Miller IJ, Bartoshuk LM (1991) Taste perception, taste bud distribution, and spatial relationship. In: Getchell TV ed. Smell and taste in health and disease. Raven Press, New York, pp. 205-233.

27. M'Kendrick JG, Snodgrass W (1893) The physiology of the senses. Charles Schriber's Sons, New York, pp. 70-79.

28. Nelson GM (1998) Biology of taste buds and the clinical problem of taste loss. Anat Rec, 253: 70-78.

29. Newman L, Haryono R, Keast R (2013) Functionality of fatty acid chemoreception: a potential factor in the development of obesity? Nutrients, 5: 1287-1300.

30. Purves D, Augustine GJ, Fitzpatrick D, et al. (eds.) (2001) Neuroscience. 2nd Ed. Sinauer Associates, Sunderland.

31. Reed DR, Knaapila A (2010) Genetics of taste and smell: poisons and pleasures. Prog Mol Biol Transl Sci, 94: 213-240.

32. Richardson TG (1854) Elements of human anatomy: general, descriptive, and practical. Lippincott, Grambo, and Company, Philadelphia, p. 556.
33. Ridge B (1844) Glossology: or, the additional means of diagnosis of disease to be derived from indications and appearances of the tongue. John Churchill, London, p. 46.

34. Rolls BJ, Fedoroff IC, Guthrie JF (1991) Gender differences in eating behavior and body weight regulation. Health Psychol, 10: 133-142.

35. Standring S ed. (2008) Gray's anatomy: the anatomical basis of clinical practice, fortieth edition. Churchill-Livingston/Elsevier, New York, pp. 486-487.

36. Stöhr P (1901) Text-book of histology including the microscopic technique. Billstein EL (trans.) Schaper A ed. P. Blakiston's Son and Co, Philadelphia, pp. 224-226.

37. Tepper BJ, Nurse RJ (1998) PROP taster status is related to fat perception and preference. Ann NY Acad Sci, 855: 802-804.

38. Todd RB ed. (1852) The cyclopaedia of anatomy and physiology. Vol. 4. Part 2. Longman, Brown, Green, Longmans, and Roberts, London, p. 1137.

39. Todd RB, Bowman W (1850) The physiological anatomy and physiology of man. Lea and Blanchard, Philadelphia, pp. 379-381.

40. Walmsley $T$ (1922) A manual of practical anatomy: a guide to the dissection of the human body. Part 3. Longmans, Green, and Co., London, p. 172.

41. Wansink B, Cheney MM, Chan N (2003) Exploring comfort food preferences across age and gender. Physiol Behav, 79: 739-747.

42. Wardle J, Haase AM, Steptoe A, Nillapun M, Jonwutiwes K, Bellisle F (2004) Gender differences in food choice: the contribution of health beliefs and dieting. Ann Behav Med, 27: 107-116.

43. Weiffenbach JM, Baum BJ, Burghauser R (1982) Taste thresholds: quality specific variation with human aging. J Gerontol, 37: 372-377.

44. Westenhoefer J (2005) Age and gender dependent profile of food choice. Forum Nutr, 57: 44-51.

45. Witt M, Reutter K (1997) Scanning electron microscopical studies of developing gustatory papillae in humans. Chem Senses, 22: 601-612.

46. Witt M, Reutter K, Miller IJ Jr. (2003) Morphology of the peripheral taste system. In: Doty RL ed. Handbook of olfaction and gestation, second edition. Marcel Dekker, Inc., New York, p. 1072.

47. Yackinous CA, Guinard JX (2002) Relation between PROP (6-n-propothiouracil) taster status, taste anatomy and dietary intake measures for younger men and women. Appetite, 38: 201-209.

48. Zylan KD (1996) Gender differences in the reasons given for meal termination. Appetite, 26: 37-44. 